\title{
UJI AKTIVITAS ANTIOKSIDAN PADA GANGGANG COKELAT ( Sargassum polycystum ) DAN GANGGANG HIJAU (Euchema cottonii) PADA PERAIRAN DAHI' AE
}

\author{
Melkianus Mola Kore, Sonya Titin Nge, Merpiseldin Nitsae \\ Program Studi Pendidikan Biologi, Fakultas Keguruan Dan IImu Pendidikan, Universita Kristen Artha \\ Wacana, Kupang-NTT \\ Coressponding Author : melkikore94@gmail.com, merpinitsae@gmail.com
}

\begin{abstract}
ABSTRAK
Rumput laut merupakan tumbuhan yang hidup di laut dan merupakan jenis makroalga. Tanaman ganggang ini adalah ganggang multiseluler devisi Thallophyta. Rumput laut tidak termaksud tumbuhan sejati karena tidak memiliki akar, batang dan daun. Penelitian ini bertujuan untuk mengetahui aktivitas antioksidan pada ganggang cokelat jenis Sargassum polycystum dan ganggang hijau jenis Eucheuma cottonii pada perairan Dahi'Ae. Penelitian ini bersifat eksperimental dengan mengunakan metode 1,1-diphenyl-2-picrylhydrazi (DPPH), dengan mengunakan 3 variasi konsentrasi (50 ppm, 75 pm, dan 100 ppm) dan 5 kali ulangan. Data yang diperoleh dianalisis untuk mendaptkan nilai \% IC50. Dari plot tersebut akan diperoleh persamaan regresi linear $y=a x+b$. Berdasarkan persamaan ini aktivitas antioksidan secara berturut-turut pada Sargassum polycystum adalah 242,02 ppm dan Euchema cottoni adalah 169,06 ppm. Kedua sampel tersebut tergolong dalam aktivitas antioksidan sedang, sehingga perlu dianalisis aktivitas antioksidan untuk $S$. polycystum pada konsentrasi tinggi sedangkan E.cottoni pada konsentrasi rendah.
\end{abstract}

Kata Kunci : Antioksidan, Sargassum polycystum, Euchema cottoni, Metode DPPH, perairan Dahi' Ae.

\section{ABSTRACT}

Seaweed is a kind of macro algae plant which lives in the sea. This alga is multicellular algae in Thallophyta division. Seaweed is not a kind of frond because there are no roots, steam and leaf. The aim of this research is to know the antioxidant activity of brown algae, Sargassum Polycystum type and green algae Euchema Cottoni type in Dahi' Ae waters. This research is experimental research which used 1,1 d-diphenyl-2-picrylhydrazi (DPPH) method, with 3 variations concentrations (50 ppm, $75 \mathrm{pm}$ and $100 \mathrm{ppm}$ ) and 5 times repetitions. The data was found were analyzes to found score $\% 1 C 50$. From that plot will found linear regression equation which is $y=a x$ $+b$. Based on this equation the antioxidant activity successively in Sargassum Polycystum is 242,02 ppm and 169,06 ppm in Euchema cottoni. Both of those sample classified into medium antioxidant activity, so there is need to analyzed the antioxidant activity for S. Polycystum used high concentration and low concentration for E. cottoni.

Key Words: Antioxidant, Sargassum Polycystum, Euchema Cottonii, DPPH Method, Dahi' Ae Waters. 


\section{PENDAHULUAN}

Rumput laut merupakan tumbuhan yang hidup di laut dan merupakan jenis makroalga. Tanaman ganggang ini adalah ganggang multiseluler divisi Thallophyta. Rumput laut tidak termasuk tumbuhan sejati karena tidak memiliki akar, batang dan daun. Tumbuhan ini biasanya hidup di dasar perairan masih terkena cahaya matahari. Berdasarkan pigmen, warna rumput laut terbagi atas 4 jenis yaitu ganggang biru (Cynophyceae), ganggang hijau (Clorophyceae), ganggang merah (Rodophyceae), dan ganggang cokelat (Phaeophyceae) (Yudhi, 2009).

Rumput laut memiliki nutrisi yang sangat beragam dengan kadar yang cukup tinggi, mencapai 10-20 kali lipat dibandingkan dengan tanaman darat. Rumput laut menghasilkan senyawa koloid yang disebut fikokoloid yakni agar, alginat, dan keraginan (Kadi, 2004); oleh karena itu rumput laut menjadi sumber pembuatan tepung keraginan yang dapat diolah menjadi produk lain, selain untuk sumber pangan dan hidrokoloid, rumput laut juga sebagai antikanker, mencegah kardiovaskuler, makanan diet, bahan obat- obatan serta klorofil sebagai antioksidan.

Kabupaten Sabu Raijua merupakan pusat inkubator rumput laut di manakluster pengembangannya tersebar di seluruh kecamatan. Kecamatan Raijua salah satu kecamatan yang menjadi sentra pengembangan rumput laut terbesar di Kabupaten Sabu Raijua. Sebagian besar masyarakat Kabupaten Sabu Raijua khususnya kecamatan Raijua bermata pencaharian sebagai nelayan rumput laut. Oleh karena itu, pantai yang terdapat di Kecamatan Raijua ini dimanfaatkan sebagai tempat budidaya rumput laut. Kegiatan budidaya rumput laut sendiri di kecamatan Raijua ini sudah berlangsung sejak tahun 2002 dan terus berkembang sampai dengan saat ini. Sejak awal pengembangannya, rumput laut terbukti memiliki sangat banyak kontribusi kepada masyarakat di kecamatan Raijua khususnya diantaranya pengentasan kemiskinan serta penyerapan tenaga kerja.

Rumput laut menghasilkan berbagai jenis antioksidan untuk menangkal tekanan lingkungan (Lesser, 2006). Oleh karena itu, rumput laut merupakan sumber potensial dari antioksidan baru. Sebagai tambahan, antioksidan lebih diterima dari pada sintesis antioksidan karena tidak mengandung bahan kimia kontaminan dan menampilkan berbagai fungsi yang bermanfaat. Dengan demikian, antioksidan alami dianggap aman untuk digunakan sebagai bahan dalam obat, suplemen makanan, dan kosmetik dengan tujuan meningkatkan kesehatan konsumen, mengurangi efek penyakit berbahaya dan lainnya sebagai aspek yang lebih luas dari fungsi sistem kekebalan tubuh (Shahidi, 2009). Tujuan dalam penelitian ini adalah untuk mengetahui aktivitas antioksidan pada ganggang cokelat jenis Sargassum polycystum dan ganggang hijau jenis Eucheuma cottonii yang terdapat pada perairan Dahi'Ae.

\section{Tempat Dan Waktu Penelitian}

\section{METODE PENELITIAN}

Pengambilan Sampel dilakukan di Perairan Dahi'Ae, Kelurahan Ledeunu, Kecamatan Raijua, Kabupaten Sabu Raijua dan di analisis di Divisi Laboratorium Material-Energi-informatika UPT Laboraturium Riset Terpadu Universitas Nusa Cendana Kupang pada bulan Oktober sampai dengan November 2017.

\section{Alat dan Bahan}

Alat-alat yang diperlukan dalam penelitian ini meliputi spektrofotometer UV-Visible, rotary vacuum evaporator, vortex, tabung reaksi, gelas ukur, pipet tetes, pipet mikro, labu Erlenmeyer, labu ukur, kaca arloji, coolbox, pisau, karung, gunting, kertas saring, saringan (ayakan).

Bahan utama yang digunakan dalam penelitian ini adalah rumput laut cokelat (Sargassum polycystum) dan rumput laut hijau (Euchema cottoni), yang diambil dari perairan Dahi'Ae, Kelurahan Ledeunu, Kecamatan Raijua, Kabupaten Sabu Raijua. Bahan-bahan lain yang dibutuhkan untuk ekstraksi S. polycystum dan Eucheuma cottonii meliputi metanol. Bahan yang digunakan untuk uji antioksidan meliputi ekstrak kasar metanol Pro Analis (p.a), Kristal 1,1-difenil-2-pikrilhidrazil (DPPH).

\section{Metode Penelitian}


Jenis penelitian yang dilakukan adalah penelitian eksperimental. Metodologi penelitian ini meliputi pengumpulan dan preparasi bahan, pembuatan ekstrak, dan uji aktivitas antioksidan dengan menggunakan metode DPPH ( Andayani et al., 2008).

\section{Prosedur Penelitian}

\section{Pengambilan Sampel}

Pengambilan sampel rumput laut dilakukan dengan cara memetik langsung dari substratnya pada saat surut. Rumput laut yang telah diambil di isi dalam karung, diberi label dan disimpan dalam coolbox yang telah berisi air laut untuk menjaga kesegaran rumput laut selama perjalanan menuju laboratorium. Preparasi rumput laut cokelat (Sargassum polycystum) dan rumput laut hijau (Eucheuma cottonii) dimulai dengan proses pencucian, pengeringan dan penggilingan. Rumput laut segar dicuci dengan menggunakan air tawar. Sampel dikeringkan di tempat yang terlindung dari sinar matahari secara langsung selama \pm 10 hari. Rumput laut yang telah kering dihaluskan menggunakan blender dan dimasukkan ke dalam wadah kemudian ditimbang menggunakan neraca analitik dan disimpan dalam kondisi kering untuk selanjutnya dilakukan proses ekstraksi.

\section{Ekstraksi Sampel}

Tahap selanjutnya adalah ekstraksi bahan aktif. Metode ekstraksi yang digunakan adalah metode ekstraksi tunggal yang mengacu pada (Quinn, 1988 dalam Darusman et al. 1995). Pelarut yang digunakan dalam penelitian ini yaitu pelarut metanol. Masing - masing sampel dihancurkan ditimbang sebanyak 150 gram dan dimaserasi dengan pelarut metanol sebanyak $500 \mathrm{ml}$ selama 48 jam. Hasil maserasi yang berupa larutan kemudian disaring dengan kertas saring sehingga diperoleh filtrat dan residu. Filtrat yang diperoleh dievaporasi hingga pelarut memisah dengan ekstrak menggunakan Rotary Vacuum Evaporator pada suhu kurang dari $45^{\circ} \mathrm{C}$. Ekstrak ini dibagi menjadi dua, yang pertama ekstrak $S$. polycystum dan kedua ekstrak Euchema cottoni.

\section{Uji Aktivitas Antioksidan Dengan Metode DPPH}

Uji aktivitas antioksidan dengan metode DPPH pertama kali dijelaskan oleh Blois. Uji aktivitas antioksidan yang dilakukan pada penelitian ini menggunakan prosedur Blois, yaitu absorbansi yang dihitung dari $1 \mathrm{ml}$ sampel dicampur $1 \mathrm{ml}$ DPPH dan diencerkan dengan $2 \mathrm{ml}$ methanol (Molyneux, 2004).

\section{Pembuatan Larutan DPPH}

Sebanyak 2,5 mg DPPH dilarutkan dalam $25 \mathrm{ml}$ metanol sehingga diperoleh konsentrasi 100 $\mu \mathrm{g} / \mathrm{ml}$ (Molyneux, 2004).

\section{Optimasi Panjang Gelombang DPPH}

Larutan DPPH dengan konsentrasi $100 \mu \mathrm{g} / \mathrm{ml}$ yang telah dibuat diukur absorbansinya pada panjang gelombang 400-700 nm ditentukan $\lambda$ optimumnya ( Molyneux, 2004).

\section{Pengujian Absorbansi Larutan Blanko}

Sebanyak $1 \mathrm{ml}$ larutan DPPH $100 \mu \mathrm{g} / \mathrm{ml}$ dimasukkan dalam tabung reaksi lalu ditambah $2 \mathrm{ml}$ metanol kemudian dihomogenkan. Larutan diinkubasi dalam penangas air $37{ }^{0} \mathrm{C}$ selama 30 menit kemudian diukur absorbansinya pada panjang gelombang optimum, ( Molyneux, 2004).

\section{Pengujian Ekstrak}

Sebanyak $25 \mathrm{mg}$ dari ekstrak rumput laut cokelat (Sargassum polycystum) dan rumput laut hijau (Euchema cottoni),) masing- masing dilarutkan dalam $25 \mathrm{ml}$ metanol Pro Analis (p.a) $>99,5 \%$ sehingga diperoleh konsentrasi $1000 \mu \mathrm{g} / \mathrm{ml}$. Dilakukan pengenceran sehingga diperoleh larutan dengan konsentrasi $50 \mu \mathrm{g} / \mathrm{ml}, 75 \mu \mathrm{g} / \mathrm{ml}$ dan $100 \mu \mathrm{g} / \mathrm{ml}$. Caranya dengan memipet larutan induk berturut-turut sebanyak $0,5 \mathrm{ml} ; 0,75 \mathrm{ml} ; 1 \mathrm{ml}$, dimasukkan pada labu ukur $10 \mathrm{ml}$ dan diencerkan dengan metanol pro analis (p.a) hingga tanda batas. Sebanyak $2 \mathrm{ml}$ dari masing-masing konsentrasi larutan sampel (ekstrak) dimasukkan dalam tabung reaksi, ditambah $2 \mathrm{ml}$ DPPH $100 \mu \mathrm{g} / \mathrm{ml}$ dan diencerkan dengan $2 \mathrm{ml}$ metanol pro analis (p.a) kemudian dihomogenkan. Masing- masing larutan dalam tabung reaksi diinkubasi dalam penangas air $37^{0} \mathrm{C}$ selama 30 menit dan diukur absorbansinya satu per satu pada $\lambda$ max (Molyneux, 2004).

\section{Uji Aktivitas Antioksidan}


Data hasil absorbansi masing-masing sampel digunakan untuk mencari \% inhibisinya. Perhitungan yang digunakan adalah :

$\%$ aktivitas antioksidan $=\frac{\text { Abs blangko-Abs sampel }}{\text { Abs blangko }} X 100 \%$

Keterangan : Abs blanko = Absorbansi pada DPPH tanpa sampel; AbsSampel = Absorbansi pada DPPH setelah ditambah sampel

Hasil perhitungan persen (\%) inhibisi disubstitusikan ke dalam persamaan linear $Y=a X+b . Y$ $=\%$ Inhibisi $a=$ Gradien $X=$ Konsentrasi $(\mu \mathrm{g} / \mathrm{ml}) \mathrm{b}=$ Konstanta. Persamaan linear yang dihasilkan digunakan untuk memperoleh nilai IC50. Nilai IC50 merupakan konsentrasi yang diperoleh pada saat $\%$ inhibisi sebesar 50 dari persamaan $Y=a X+b$. Pada saat $\%$ Inhibísi $i=50$, maka untuk menghitung nilai IC50 persamaannya menjadi: $50=\mathrm{aX}+\mathrm{b} . X=\frac{50-\mathrm{b}}{a}$, dimana harga $\mathrm{X}$ adalah IC50 dengan satuan $\mu \mathrm{g} / \mathrm{ml}$.

\section{Analisis Data}

Data yang diperoleh diplotkan dalam grafik sehingga diperoleh persamaan regresi linear. Berdasarkan persamaan regresi tersebut akan diperoleh nilai IC50.

\section{HASIL DAN PEMBAHASAN \\ 1. Rumput laut hijau (Euchema cottoni) dan rumput laut cokelat (Sargassum polycystum).}

Rumput laut hijau (E. cottoni) dan rumput laut cokelat (S. polycystum) yang diambil dari perairan Dahi' Ae, Kecamatan Raijua, Kabupaten Sabu Raijua. Jenis rumput laut ini merupakan jenis rumput laut yang dibudidaya (E. cottoni) dan tidak dibudidaya (S. polycystum) oleh masyarakat setempat. Pemanfaatan E. cottoni oleh masyarakat setempat hanya sebagai bahan mentah yang dijual kepada pedagang untuk keperluan rumah tangga, dengan demikian pemanfaatan $E$. cottoni ini tidak dimaksimalkan dengan baik, sedangkan $S$. polycystum merupakan jenis rumput laut cokelat yang tumbuh dan tidak dibudidayakan oleh masyarakat setempat serta keberadaanya cukup banyak.

Rumput laut jenis ini tumbuh dengan memerlukan sinar matahari untuk proses fotosintetis. Rumput laut E. cottoni hidup pada lapisan fotik, yaitu kedalaman sejauh sinar matahari masih mampu mencapainya, sedangkan S. polycystum merupakan salah satu contoh rumput laut cokelat yang mempunyai holdfast, stipe, serta blade. Tubuh S. polycystum didominasi oleh warna cokelat dengan bentuk talus silindris. Tubuh utama bersifat diploid atau merupakan sporoit, yang mana talus mempunyai cabang yang menyerupai tumbuhan angiospermae.

Rumput laut jenis ini memiliki penampakan bentuk agak gepeng, licin, dan batang utamanya agak kasar. E. cottoni dan S.polycystum dikeringkan dengan tujuan membuat rumput laut menjadi lebih mudah untuk dihancurkan, sehingga penghalusan juga menjadi lebih mudah. Pengeringan merupakan proses pengurangan kadar air sampai tanda batas terbaik, yaitu 8-10\%, karena pada tingkat kadar air tersebut, sampel terhindar dari pencemaran yang disebabkan oleh jamur, bakteri dan insektisida. Proses pengeringan yang mengurangi kadar air ini juga berguna dalam proses evaporasi. E. cottoni dan S. polycystum yang sudah dikeringkan diubah menjadi bentuk serbuk dengan cara diblender hingga halus, dan disaring menggunakan penyaring (ayakan) dengan ukuran 60-250 mesh, tujuan penghalusan sampel yaitu untuk memperbesar ukuran permukaan sampel sehingga proses ekstraksi berjalan optimal karena semakin luas permukaan sampel maka interaksi antara pelarut dan sampel semakin besar, dapat dilihat pada gambar 1 . 

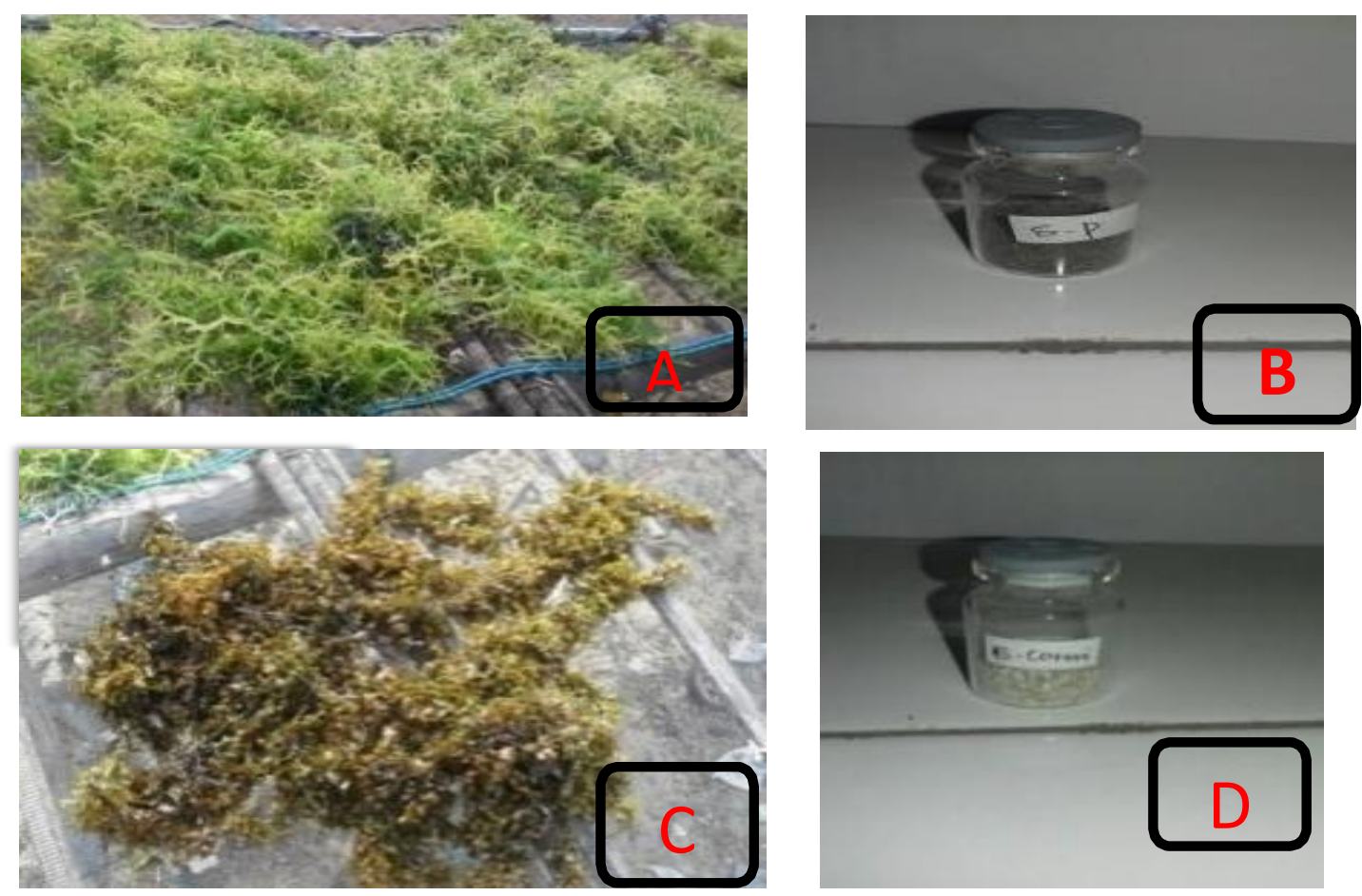

Gambar 1 (a) Rumput laut E. cottoni ; (b) Serbuk E. cottoni ; (c) Rumput laut S. polycystum ; (d) Serbuk S. polycystum (Dok. Pribadi, 2017).

\section{Ekstrak kasar E. cottoni dan S. polycystum.}

Tahap selanjutnya adalah ekstraksi bahan aktif. Metode yang digunakan adalah metode ekstraksi tunggal yang mengacu pada Quinn, (1988) dalam Darusman et al. (1995). Rumput laut hijau (E. cottoni) dan rumput cokelat (S. polycystum) diekstrasi dengan metode maserasi (ekstraksi cara dingin). Metode ini dipilih karena dapat mencegah terurainya metabolit yang tidak tahan pemanasan. Ekstraksi dilakukan dengan menggunakan pelarut tunggal dengan pelarut metanol.

Pelarut metanol memiliki titik didih sebesar $64,7^{0} \mathrm{C}$ pada tekanan $760 \mathrm{mmHg}$. Menurut Matanjun et al.(2008), Ekstraksi dengan menggunakan metanol memilki hasil rendemen tertinggi karena banyak kompenen bioaktif yang larut dengan pelarut metanol. Metanol memiliki hasil rendemen yang paling maksimal untuk ekstraksi rumput laut.

Masing-masing sampel, rumput laut hijau (Euchema cottoni) dan rumput cokelat ( $S$. polycystum) ditimbang masing-masing sebanyak 150 gram dan kemudian dimaserasi dengan pelarut metanol sebanyak $500 \mathrm{ml}$ selama 48 jam dan diaduk beberapa kali hingga sampelnya merata. Pengadukan ini bertujuan untuk memperbesar kemungkinan tumbukan antara bahan pelarut yang digunakan berdifusi ke dalam sel untuk melarutkan senyawa bioaktif yang dapat terlarut ke dalam pelarut tersebut dan juga pelarut yang digunakan berdifusi ke dalam sel untuk melarutkan senyawa yang terkandung didalamnya dan larutan melewati dinding sel serta bercampur dengan cairan di sekitarnya sehingga terbentuk keseimbangan. Hasil ekstraksi yang diperoleh akan bergantung pada beberapa faktor yaitu, kondisi alamiah senyawa tersebut, metode ekstraksi yang digunakan, ukuran partikel sampel, kondisi dan waktu penyimpanan, lama waktu ekstraksi, serta perbandingan jumlah pelarut dan sampel.

Filtrat yang diperoleh ditampung dan diuapkan dengan alat rotary vaccum evaporator $45^{0} \mathrm{C}$ hingga metanol menguap seluruhnya. Alat ini bekerja berdasarkan prinsip diagram fase air, yaitu tekanan udara diturunkan, maka titik didih akan turun. Tekanan yang digunakan adalah tekanan vaccum $(500 \mathrm{mmHg})$, sehingga suhu $\pm 45^{\circ} \mathrm{C}$ dapat digunakan untuk menguapkan pelarut. Kondisi demikian merupakan kondisi yang diinginkan. Hal ini karena pada saat kondisi 
tersebut lebih dari 95\% kandungan nutrisi, vitamin, ferment, dan komponen bioaktif lainnya dapat terselamatkan.

Penggunaan vaccum memungkinkan pelarut dapat menguap pada suhu rendah. Kadar air yang berkurang saat pengeringan berguna dalam evaporasi, yaitu jika air masih terkandung didalamnya, maka akan sangat sukar dipisahkan dengan menggunakan pemanasan suhu rendah karena memiliki titik didih yang lebih tinggi dari pelarut. Pemanasan yang dilakukan dengan menggunakan suhu tinggi, yaitu suhu $100^{\circ} \mathrm{C}$, tekanan 1 atm $(760 \mathrm{mmHg})$, dikhawatirkan akan merusak komponen bioaktif yang memiliki sifat sebagai antioksidan karena panas.

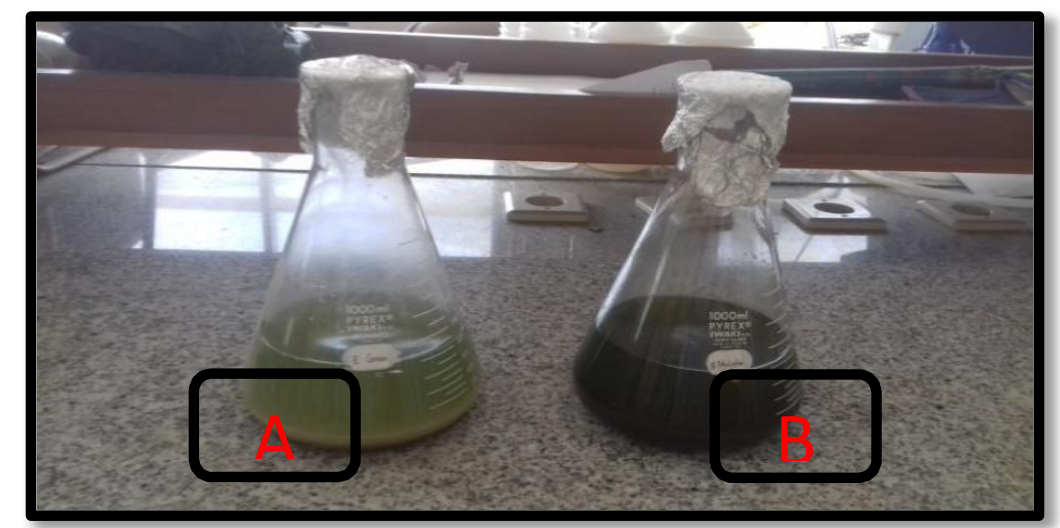

Gambar 2. (a) Ekstrak kasar E. cottoni ; (b) Ekstrak kasar. S. polycystum (Dok. Pribadi, 2017)

\section{Aktivitas Antioksidan pada ekstrak rumput laut hijau (Euchema cottoni) dan rumput laut} coklat (Sargassum polycystum).

Pengukuran absorbansi sampel rumput laut hijau (Euchema cottoni) dan rumput laut cokelat (Sargassum polycystum), masing- masing dilakukan pada konsentrasi 50 ppm, 75 ppm, dan 100 ppm. Pengenceran ini bertujuan untuk memperluas jangkauan konsentrasi dengan rentang yang konstan sehingga titik- titik persimpangan dapat disubtitusikan sebagai persamaan linear secara akurat, dengan demikian IC50 dapat diperoleh dari persamaan $\mathrm{y}=\mathrm{ax}+\mathrm{b}$.

Metode uji aktivitas antioksidan dengan menggunakan radikal bebas DPPH dipilih karena metode sederhana, mudah, cepat, peka dan hanya memerlukan sedikit sampel, akan tetapi jumlah pelarut pengencer yang diperlukan dalam pengujian ini cukup banyak. Pelarut yang digunakan adalah metanol. Metanol dipilih sebagai pelarut karena methanol dapat melarutkan kristal DPPH dan juga memiliki sifat yang dapat melarutkan komponen polar didalamnya. Uji aktivitas antioksidan dilakukan secara kuantitatif dengan menggunakan spektrofotometer UV-Vis. Hasil uji dilaporkan sebagai IC50. IC50 merupakan salah satu parameter yang biasa digunakan menginterpretasikan hasil dari pengujian DPPH. Nilai IC50 ini dapat didefinisikan sebagai konsentrasi substrat yang dapat menyebabkan berkurangnya 50\% aktivitas DPPH. Semakin kecil nilai IC50 berarti nilai aktivitas antioksidan semakin tinggi. Perhitungan persen (\%) inhibisi dimulai dengan menentukan panjang gelombang maksimal $\left(\boldsymbol{\lambda}_{\max }\right)$ dengan larutan DPPH mengunakan kisaran panjang gelombang 400-700 nm dengan mengunakan alat spektrofotometer UV-Vis dengan melihat absorbansi tertinggi maka panjang gelombang maksimumnya dipilih. Berdasarkan gambar 3. di peroleh $\lambda$ max sebesar $516 \mathrm{~nm}$. 


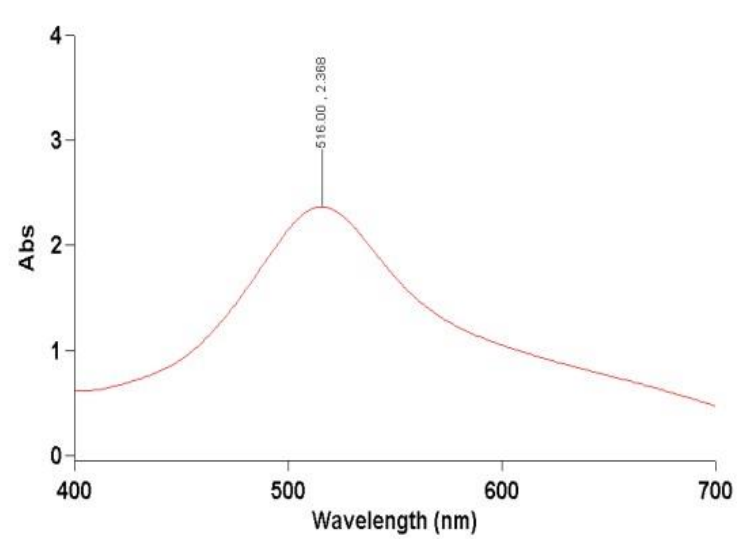

Gambar 3. Panjang gelombang maksimal (Amaks) S. polycystum dan E. cottoni.

Berdasarkan data tabel 1 lampiran 3. dapat disubtitusikan ke dalam persamaan linear $y=a x+b$. persamaan dapat dilihat pada gambar 4 .

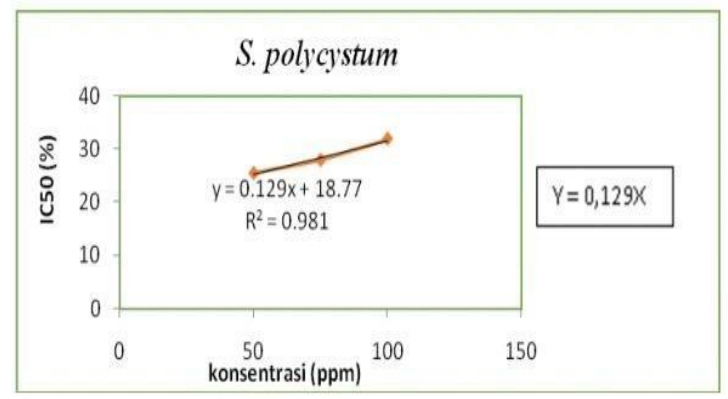

Gambar 4. Grafik persen (\%) inhibisi pada sampel S. Polycystum.

Dari persamaan grafik pada gambar 4. dapat disubtitusikan dalam persamaan linear $Y$ $=a X+b$ maka diperoleh nilai IC50 242.09 ppm. Nilai ini menunjukan bahwa S. polycystum tergolong memiliki aktivitas yang sedang. Berdasarkan data tabel 2 lampiran 3 . dapat disubtitusikan kedalam persamaan linear $Y=a X+b$. Persamaan dapat dilihat pada gambar 5 .

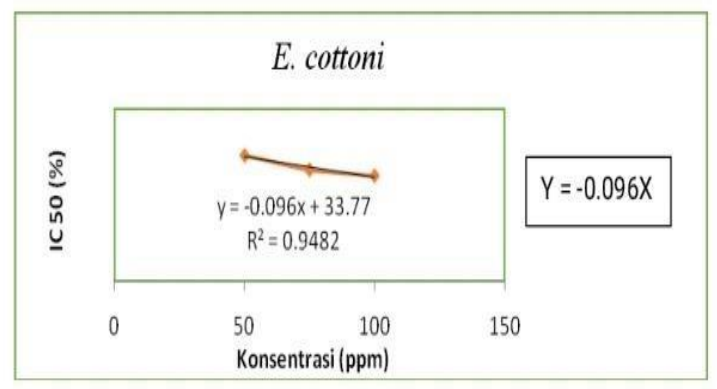

Gambar 5. Grafik persen (\%) inhibisi pada sampel E. Cottoni

Dari persamaan grafik pada gambar 5. dapat disubtitusikan dalam persamaan linear $Y$ $=\mathrm{aX}+\mathrm{b}$ maka diperoleh nilai IC50 adalah 169,06 ppm. Nilai ini menunjukan bahwa E. cottoni tergolong memiliki nilai aktivitas antioksidan yang sedang. Berdasarkan perhitungan grafik persen (inhibisi) antara E. cottoni dan S. polycystum menunjukkan terdapat perbedaan antara kedua sampel tersebut. Pada $S$. polycystum dengan bertambahnya konsentrasi ekstrak maka absorbansi sampel akan naik dan nilai tingkat inhibisi akan semakin naik pula, sedangkan pada E. cottoni menunjukkan bahwa dengan bertambahnya konsentrasi ekstrak, maka absorbansi sampel naik dan tingkat inhibisinya akan semakin menurun. Absorbansi sampel turun karena 
elektron pada DPPH menjadi berpasangan dengan elektron sampel yang mengakibatkan warna berubah dari ungu menjadi pekat kuning bening dan absorbansi pada panjang gelombang pada $516 \mathrm{~nm}$ akan menghilang, hal ini sesuai dengan pernyataan Green (2004). Nilai tingkat inhibisi meningkat seiring meningkatnya konsentrasi sampel dikarenakan semakin banyak senyawa antioksidan pada sampel yang menghambat radikal bebas.

Uji aktivitas antioksidan menunjukan bahwa ekstrak rumput laut $S$. polycystum memilik nilai IC50 242,09 ppm. Hal ini berarti bahwa pada konsentrasi 242, 09 ppm sampel dapat menghambat $50 \%$ radikal bebas DPPH. Menurut Jun et al. (2003) ekstrak tersebut mempunyai aktivitas antioksidan yang sedang. Dan nilai ekstrak kasar rumput E. cottoni mempunyai nilai IC50 sebesar 169,06 ppm dan mempunyai antioksidan yang tergolong sedang, karena mempunyai nilai 101-250 ppm.

Aktivitas antioksidan dinyatakan dalam IC50 berdasarkan pengukuran nilai absorbansi dan persen (\%) inhibisi dapat diperoleh nilai IC50 dari masing-masing ekstrak metanol E. cottoni dan $S$. polycystum. Jun et al (2003) berpendapat bahwa senyawa dikatakan sebagai antioksidan sangat kuat apabila nilai IC50 kurang dari 50 ppm, apabila nilai IC50 antara 50-100 ppm kuat, sedang apabila nilai IC50 101-250 ppm, lemah apabila IC50 berkisar antara 250-500 ppm. Berdasarkan hasil penelitian di atas disimpulkan bahwa E. cottoni dan S. polycystum termaksud kategori antioksidan sedang, tetapi memiliki nilai IC50 yang berbeda.

\section{Simpulan}

\section{PENUTUP}

Berdasarkan hasil penelitian ekstrak kasar rumput laut jenis S. polycystum dan E. cottoni menunjukan nilai aktivitas antioksidan secara berturut-turut adalah 242,09 ppm dan 169,06 ppm dan tergolong dalam aktivitas antioksidan yang sedang.

\section{Saran}

1. Perlu dilakukan penelitian lanjutan mengenai uji aktivitas antioksidan pada $E$. cottoni pada rentang konsentrasi 0-50 ppm.

2. Perlu dilakukan penelitian lanjutan mengenai aktivitas antioksidan pada S. polycystum pada rentan konsentrasi lebih besar dari 100 ppm.

3. Perlu dilakukan penelitian lanjutan mengenai aktivitas antioksidan menggunakan fraksi pelarut yang berbeda.

4. Identifikasi dan isolasi senyawa antioksidan pada E. cottoni dan S. polycystum.

\section{DAFTAR PUSTAKA}

Andayani, R., Y Lisawati, Maimunah. 2008. Penentuan Aktivitas Antioksidan, Kadar Fenolat Total dan Likopen Pada Buah Tomat (Solanun licopersium L). Jurnal Sains dan Teknologi Farmasi.,13 (1).

Darusman LK. Sajuthi D. Komar \& Pamungkas J.1995.Ekstraksi komponen bioaktif sebagai bahan obat dari karang-karangan, bunga karang dan ganggang laut di perairan Pulau Pari Kepulauan Seribu, Buletin kimia, Institut Pertanian Bogor.

Green, R.J (2004). Antioxidant activity of Peanut plant tissues. Nort Caroline State University: Departemen Of Food Science, Raleigh.

Jun, M.H.Y., J., Fong, X., Wan, C.S., Yang, C.T., Ho. 2003. Camparison of Antioxidan Activities of Isoflavones Form Kudzu Root (Puerarua labata O), Journal Food Science Institue of Technologist, 68; 2117-2122. 25-36.

Kadi, A. 2004. Potensi Rumput Laut Dibeberapa Perairan Pantai Indonesia. Oesena. 29(4): 
Lesser MP. 2006. Oxidativ strees in marine environments biochemistry \& physiological. Physiol $68: 253-278$

Matanjuan, P., S. Mohamed, N.M. Mustapha, K. Muhammad \& C.H.Ming, 2008. Antioxidant activities and phenolics content of eight species of seaweads from north Borneo. J. Appl. Phycol., 20: 367-373.

Molyneux, P. 2004 The use of stable free radical diphenylpicrylhydrazyl (DPPH) for estimating antioxidant activity. Journal of Science Technology, Volume 26, No. 2.

Shahidi F. 2009. Phenolics in food \& natural products: an overview. Phenolic Campounds in Food \& Natural Health Products. Edited by Shahidi. USA. Oxford University Press. pp 1-8

Yudhy. 2009. Kriteria Kualitas Rumput Laut yang Dijual. Tersedia di http://kir/2011/11/kriteria-kualitas- rumput-laut-yang-dijual.html. Diakses pada tanggal 21 September 2016 
Indigenous Biologi Jurnal pendidikan dan Sains Biologi Volume 1(3) 2018 